\title{
Perbedaan Persepsi Turki dan North Atlantic Treaty Organization terhadap Ancaman Terorisme: Permasalahan Kurdi
}

\author{
Alvin Christopher Simbolon \\ Hubungan Internasional Fakultas IImu Sosial dan IImu Politik Universitas Indonesia \\ e-mail: alvin_simbolon@yahoo.co.id
}

\section{Abstract}

This paper aims to describe the attitudes and policies taken by Turkey in dealing with the People's Protection Units (YPG); a Kurdish militia organization in Syria, which is seen as a terrorism threat to Turkey, but not to NATO. The lack of literature describing the dynamics of Turkey-NATO relations in terms of threat perception, especially those closely related to the YPG threat, is a gap that will be filled by the researcher in this paper. This paper argues that Turkey has taken actions and attitudes that tend to violate the boundaries of norms and values in the NATO alliance. Turkey played its part unilaterally in facing the YPG. This research uses the analytical framework of Intra-Alliance Opposition by Oya Dursun Ozkanca, which consists of three processes in the alliance. It describes when state tools are used in the alliance and for what purposes. It is hoped that this article will contribute to the development of the empirical and scientific literature on the Intra-Alliance Opposition using a case study of Turkey's foreign policy.

Keywords: foreign policy, intra alliance opposition, perception, terrorism, threat

\section{Abstrak}

Tulisan ini bertujuan untuk mendeskripsikan sikap dan kebijakan yang diambil Turki dalam menghadapi Unit Perlindungan Rakyat (YPG); sebuah organisasi milisi Kurdi di Suriah, yang dipandang sebagai ancaman terorisme bagi Turki, namun tidak demikian bagi NATO. Minimnya literatur yang menggambarkan dinamika hubungan Turki-NATO dari sisi persepsi ancaman, khususnya yang berkaitan erat dengan ancaman YPG, menjadi celah yang akan diisi oleh peneliti dalam tulisan ini. Tulisan ini memiliki argumen bahwa Turki telah mengambil tindakan dan sikap yang cenderung melanggar batasan norma dan nilai dalam aliansi NATO. Turki memainkan perannya secara unilateral dalam menghadapi YPG. Penelitian ini menggunakan kerangka kerja analisis Oposisi dalam Aliansi dari Oya Dursun 
Ozkanca yang memperlihatkan tiga proses Oposisi dalam Aliansi dan menggambarkan kapan alat-alat kenegaraan tertentu digunakan dalam aliansi dan untuk tujuan apa. Artikel ini diharapkan berkontribusi pada pengembangan empiris dan konseptual literatur ilmiah tentang Oposisi dalam Aliansi dengan menggunakan studi kasus kebijakan luar negeri Turki.

Kata kunci: ancaman, kebijakan luar negeri, oposisi dalam aliansi, persepsi, terorisme

\section{Pendahuluan}

Perang Dingin melahirkan polarisasi dalam sistem internasional yang dipertunjukkan oleh pembentukan Aliansi Blok Timur (Pakta Warsawa) dan Blok Barat (North Atlantic Treaty Organization - NATO). Namun pasca Perang Dingin tatanan sistem polaritas tersebut telah berubah, yang ditandai dengan runtuhnya Uni Soviet yang menjadi ancaman bersama dari NATO (Sudira, 2017: 160). Dengan ketiadaan ancaman yang sebelumnya menjadi suatu ancaman kolektif bagi aliansi Barat, persepsi terhadap ancaman mengalami ketidakselarasan di antara anggota aliansi. Perbedaan persepsi ini antara lain terlihat antara Turki dengan NATO. Dinamika hubungan Turki, yang merupakan anggota NATO sejak tahun 1952, dengan aliansi selama tiga dekade terakhir ditandai dengan ketidakpastian dan kekhawatiran. Pasca Perang Dingin, Turki mulai mempertanyakan relevansi NATO sebagai basis dari kebijakan luar negeri dan keamanan Turki.

Salah satu tantangan bagi hubungan Turki dengan NATO adalah permasalahan bangsa Kurdi. Secara domestik, integrasi etnis dan nasional telah menjadi penting bagi Turki pasca Perang Dingin. Sebaliknya, bangsa Kurdi telah lama memiliki keinginan untuk mendirikan sebuah negara-bangsa (nation-state) bagi etnis mereka. Suku Kurdi merupakan bangsa terbesar keempat di Timur Tengah setelah bangsa Arab, Turki, dan Persia, dan terpusat di wilayah empat negara Timur Tengah antara lain Turki, Iran, Irak, dan Suriah (Anderson \& Anderson, 2013: 260).

Upaya Kurdi untuk mendirikan negara-bangsa mengancam integritas teritorial Turki. Melalui operasi militer, Turki telah mencoba untuk menghancurkan pasukan bersenjata Kurdi di Suriah dan Irak. Dalam memecahkan permasalahan nasional yang terkait dengan aktivitas etnis Kurdi di dalam negeri, sikap Turki terhadap Partai Kerja Kurdi (PKK) sangatlah keras. Selama empat dekade terakhir, Turki telah melancarkan perang terhadap PKK, sebuah kelompok gerilyawan separatis-Marxist yang ditetapkan sebagai organisasi teroris oleh Amerika Serikat dan Turki (Gurcay, t.t.). 
Konflik ini bisa dikategorikan sebagai insurgency (pemberontakan) dilihat dari durasi konflik yang telah berlangsung selama empat dekade dan hingga saat ini belum terselesaikan (Fathurachmi, 2014: 3). Karena PKK memiliki ikatan yang dalam dengan Unit Perlindungan Rakyat (YPG) yang berbasis di Suriah, maka YPG dan perwakilan politiknya, Partai Persatuan Demokrat (PYD) pun menjadi target Turki (Gurcay, t.t.). Turki melihat YPG sebagai organisasi teroris yang merupakan perpanjangan dari PKK yang mana telah memperjuangkan otonomi bagi bangsa Kurdi selama berdekade di Turki (BBC News, 2019). Namun demikian, sejak tahun 2014, Amerika Serikat telah secara terbuka memberikan bantuan kepada pasukan YPG dalam melawan Islamic State of Iraq and Syria (ISIS). YPG memainkan peran terdepan dalam kelompok payung dari Amerika Serikat yang disebut dengan Pasukan Demokratik Suriah (SDF), yang juga memasukkan unsur-unsur Arab dan non-Kurdi lainnya (Zanotti \& Thomas, 2017). Pada Mei 2017, Amerika Serikat mengumumkan keputusan untuk mempersenjatai kelompok YPG secara langsung untuk menghadapi ISIS, dengan mempertimbangkan langkah-langkah untuk membatasi prospek penggunaan senjata milik Amerika Serikat oleh YPG terhadap Turki. Amerika Serikat disini tidak hanya menyediakan senjata tetapi juga pelatihan militer kepada YPG, karena memandangnya sebagai pasukan yang paling efektif dalam menghadapi ISIS.

Di bawah kepemimpinan Presiden Recep Tayyip Erdogan, respons Turki terhadap fenomena ini terlihat ofensif. Turki telah melakukan tiga operasi militer di Suriah yang dikhususkan untuk menarget pasukan Kurdi: Operation Euphrates Shield (2016-2017), Operation Olive Branch (2018), dan Operation Peace Spring (2019). Turki pada mulanya melancarkan operasi militer di Suriah pada tahun 2016 dengan tujuan untuk melawan ISIS, namun pada akhirnya berubah menjadi perlawanan terhadap YPG (Gurcay, t.t.). Operation Euphrates Shield berlangsung selama 7 bulan yang menghasilkan kemenangan Turki dalam mendapatkan kontrol di wilayah al-Bab (Hurriyet Daily News, 2017). Operasi pada tahun 2019 dirancang untuk mengusir SDF yang dipimpin oleh YPG dari wilayah Utara Suriah (Uras, 2019).

Operasi militer Turki tidak luput dari kritikan, terutama kritik yang dilontarkan oleh berbagai negara anggota NATO atas operasi tersebut. Presiden Prancis, Francois Hollande, memahami kekhawatiran Turki dalam melawan ISIS, namun mengkritik tindakan Turki terhadap YPG (Hurriyet Daily News, 2016). Menteri Luar Negeri Belanda, Bert Koenders, meminta Turki dan Kurdi Suriah untuk bekerja sama melawan ISIS alihalih berkonflik di antara mereka sendiri dan meminta kelompok Kurdi Suriah untuk dilibatkan dalam pembicaraan damai (Ara News, 2016). Turki semakin lama semakin terasingkan di dalam NATO, terutama akibat dukungan terbuka NATO terhadap YPG di Suriah utara dan keengganan NATO dalam mengusir YPG (TRT World, 2020). 
Dengan dukungan Amerika Serikat dan NATO, angkatan bersenjata Kurdi berkembang di Irak dan Suriah, membentuk rezim separatis de facto. Dengan demikian, terdapat perbedaan persepsi ancaman antara Turki dan NATO dan hal ini menimbulkan kerentanan dalam aliansi terkait konflik kepentingan individu anggota aliansi dengan kebutuhan kolektif aliansi. Tantangan selanjutnya bagi hubungan Turki-NATO adalah untuk merumuskan persepsi kolektif di antara negara anggota NATO (Wiratma \& Suharman, 2016: 15-16). Berdasarkan latar belakang tersebut penulis akan merumuskan sebuah pertanyaan yaitu mengapa Turki bersikap unilateral dalam kebijakannya terhadap kelompok YPG dan afiliasinya?

Berbagai kajian akademis telah dilakukan dalam membahas dinamika hubungan Turki-NATO, namun penulis melihat bahwasanya kajian tersebut masih terlalu luas dalam periodisasi penelitiannya dan belum secara spesifik menjelaskan satu kasus tertentu. Sejak berakhirnya masa Perang Dingin, berbagai penelitian dilakukan dalam melihat dinamika hubungan Turki-NATO melalui perspektif Realisme Struktural, Pragmatisme, Konstruktivis, Hierarki Kekuasaan, Konflik Transnasional, dan Liberalisme Institusional.

Kajian Realisme Struktural melihat bahwasanya dinamika hubungan Turki-NATO tidak lepas dari berbagai macam variabel selama dua dekade terakhir pasca Perang Dingin, yaitu geografis dan regional; dinamika transatlantik; transformasi NATO (Guvenc \& Ozel, 2012); balancing (penyeimbangan) serta co-optation (kooptasi) (Oguzlu, 2013a). Turki diprediksi akan menjadi hegemon regional dalam sepuluh tahun ke depan dan menekankan pada hubungan bilateral Turki-Amerika Serikat sebagai penentu status Turki di Timur Tengah (Erickson, 2004). Bipolaritas antara Iran dan Amerika Serikat di kawasan Timur Tengah ditekankan dalam analisis ancaman strategis bagi Turki (Martin, 2013). Hubungan Turki-NATO juga dianalisis melalui sikap konvergensi dan divergensi Turki dalam aliansi (Oguzlu, 2013b).

Kajian yang menggunakan sudut pandang pragmatisme melihat dinamika hubungan Turki-NATO melalui pendekatan berbasis kepentingan bersama dalam aliansi (Oguzlu, 2008). Selain itu Turki lebih menekankan pada kepentingan nasionalnya di Timur Tengah (Oguzlu, 2012). Kajian yang menggunakan sudut pandang Konstruktivis melihat interaksi dinamis antara NATO dan Turki dalam konteks operasi militer sebagai faktor penting dalam melegitimasi identitas yang mereka cita-citakan masing-masing di era pasca-Perang Dingin (Kinacioglu \& Gurzen, 2013). Kajian yang melihat dari sisi hirarki kekuatan mencoba mengkonseptualisasikan Turki sebagai kekuatan regional (Kardas, 2013) (Parlal Dal, 2016) dan kekuatan menengah dalam sikap dan tindakannya di kawasan (Onis \& Kutlay, 2016). 
Kajian yang menggunakan pendekatan konflik transnasional mencoba mendeskripsikan perang sipil Suriah sebagai studi kasus bagi Turki dalam mempersepsikan ancaman terorisme (Parlar Dal, 2017). Terakhir, kajian Liberalisme Institusional (Sayari, 2013) melihat Dinamika hubungan Turki-NATO dari konteks interaksi Turki dengan Barat khususnya Amerika Serikat dan melihat bahwa faktor domestik serta struktural memprediksi hubungan kedua negara ke ranah baru, dan menekankan pada kepentingan kerjasama antara kedua negara dalam aliansi (Altunisik, 2013).

Argumen yang dibangun oleh kajian-kajian akademik terdahulu mengenai dinamika hubungan Turki-NATO dapat disarikan sebagai berikut. Dinamika ini tidak terlepas dari letak geografis Turki dalam kawasan Timur Tengah yang bersifat strategis bagi aliansi. Oleh sebab itu, Turki masih dianggap sebagai negara yang penting dalam kontribusinya terhadap keamanan aliansi. Di sisi lain, pandangan Turki terhadap NATO berubah yang mulanya berdasarkan satu identitas bersama-Barat-menuju identitas yang berdasarkan pada kepentingan nasional.

Meskipun kita dapat menarik pelajaran penting dari berbagai perspektif yang digunakan, tampaknya kajian-kajian terdahulu belum secara spesifik menjelaskan perbedaan persepsi antara Turki-NATO terhadap ancaman khususnya ancaman terorisme, secara khusus YPG dengan afiliasinya di Suriah yang ditandai sebagai ancaman teroris bagi Turki namun tidak demikian bagi NATO. Untuk mengukur kekuatan hubungan strategis Turki di dalam NATO, maka NATO menjadi tempat yang bisa dilihat. Lagi pula, sekutu dalam NATO diasumsikan memiliki persepsi ancaman yang sama dan juga cara menangani ancaman tersebut (Walt, 1987). Tulisan ini akan berfokus pada sikap dan kebijakan yang diambil Turki terkait permasalahan Kurdi dan menganalisis implikasinya bagi hubungan Turki-NATO.

Penulis berargumen bahwasanya Turki telah mengambil tindakan dan sikap yang cenderung melanggar batasan nilai-nilai dalam aliansi NATO. Turki memainkan perannya secara unilateral dalam menghadapi YPG, meskipun secara terus-menerus telah meminta bantuan NATO yang dianggap telah mengabaikan Turki. Turki merasa diabaikan oleh NATO dalam menghadapi ancaman teroris. Dengan demikian, Turki akan tetap menjalankan tindakan yang sesuai dengan kepentingannya terlepas dari kepentingan bersama aliansi secara keseluruhan.

Penulis melihat literatur yang membahas aliansi secara teoretis kurang mapan dalam mengidentifikasi berbagai tingkat oposisi/konflik dalam aliansi. Oleh karena itu, tulisan ini akan mengintegrasikan alat-alat dan strategi yang diidentifikasi dalam literatur Hubungan Internasional ke dalam literatur tentang aliansi agar memiliki 
pemahaman yang lebih akurat mengenai tingkat-tingkat oposisi dalam aliansi. Dengan demikian penulis akan mencoba mengisi celah ini dengan meletakkan dinamika hubungan Turki-NATO ke dalam sebuah kerangka Oposisi dalam Aliansi. Konsep Oposisi dalam Aliansi mmebahas mengenai konflik di antara anggota aliansi atau di antara satu anggota aliansi berhadapan dengan aliansi itu sendiri (Dursun-Ozkanca, 2019: 30).

Bagian pertama dari tulisan ini akan menggunakan indikator Entangling Diplomacy (Diplomasi Menjerat) untuk melihat penggunaan aturan dan prosedur dari institusi (NATO) oleh Turki dalam mempengaruhi kebijakan luar negeri negara anggota NATO lainnya (Dursun-Ozkanca, 2019: 33). Bagian kedua akan mengaplikasikan indikator Costly Signalling (Pensinyalan Merugikan). Sejauh mana Turki mengambil sikap yang yang bertentangan dari NATO terkait masalah YPG? Pertanyaan ini akan dieksplorasi lebih lanjut dalam bagian tersebut. Bagian ketiga akan menganalisis sikap boundary breaking Turki dan akan mengaplikasikan Compellent Threats (Ancaman yang Memaksa), dan Blackmailing (Pemerasan). Tulisan akan diakhiri dengan kesimpulan yang meringkas semua argumen yang telah dipaparkan dalam bagian pembahasan.

\section{Oposisi dalam Aliansi}

Penulis akan menjawab rumusan masalah dengan meletakkan dinamika hubungan Turki-NATO ke dalam sebuah kerangka Oposisi dalam Aliansi. Konsep Oposisi dalam Aliansi didefinisikan sebagai adanya konflik antara anggota aliansi atau antara satu anggota aliansi dengan aliansi itu sendiri (Dursun-Ozkanca, 2019: 30). Anggota aliansi mungkin memiliki preferensi politik yang berbeda dan terdapat ketidakpastian mengenai persepsi tentang preferensi tersebut. Oposisi dalam Aliansi memiliki implikasi yang signifikan untuk efektivitas tanggapan aliansi terhadap masalah-masalah mendesak yang dihadapi aliansi. Karena itu, penting untuk memahami motivasi di balik perilaku Oposisi dalam Aliansi. Dalam Bagan 1 dapat dilihat tiga proses Oposisi dalam Aliansi beserta indikatornya.

Dalam tulisan ini dibahas tiga proses oposisi Turki dalam NATO dengan menggunakan indikator-indikator yang memiliki signifikansi langsung dengan topik pembahasan. Dengan demikian, tidak semua indikator dalam bagan di atas akan digunakan dalam tulisan ini. Dalam menganalisis sikap oposisi Turki dalam NATO, penulis akan mengklasifikasikan tiga proses Oposisi dalam Aliansi ke dalam empat indikator yang terdiri dari Entangling Diplomacy, Costly Signaling, Compellent Threats, dan Blackmail. Selain karena alasan simplifikasi, tiga proses Oposisi dalam Aliansi penulis reduksi menjadi empat indikator agar lebih sesuai dan sejalan dengan sikap yang diambil Turki dalam relasinya dengan NATO. 


\section{Bagan 1. Tiga Proses Oposisi dalam Aliansi}

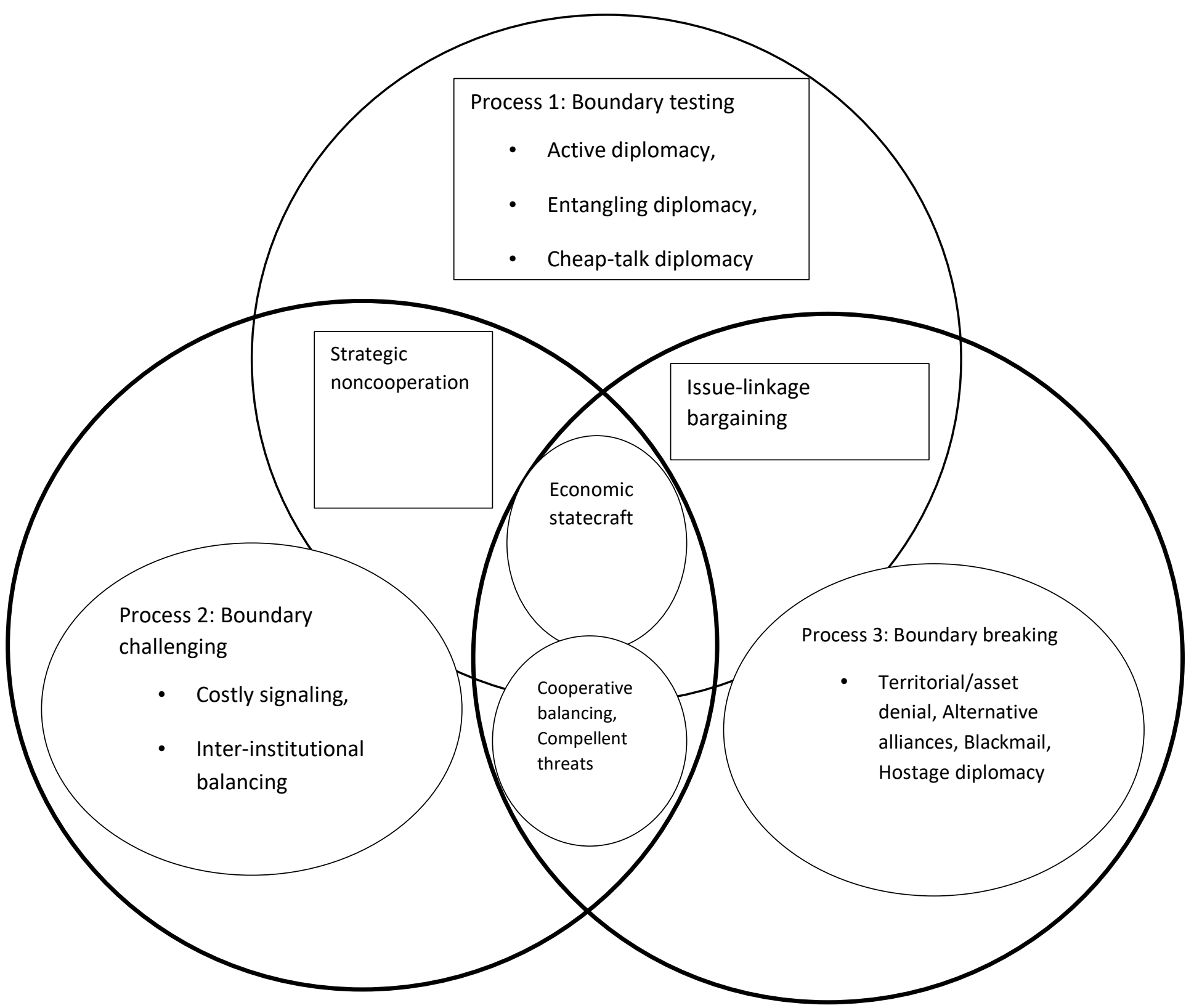

(Sumber: Dursun-Ozkanca, 2019: 31) 
Kerangka Oposisi dalam Aliansi menyajikan kondisi di mana negara menggunakan alat dan strategi yang mereka lakukan ketika terlibat dalam interaksi dalam aliansi. Dalam proses pertama Oposisi dalam Aliansi, menguji batasan adalah bagian dari upaya untuk mengetahui dan memahami apa batasannya ketika menavigasi hubungan dengan anggota aliansi lainnya. Tujuan dari proses awal menguji batasan ini adalah agar negara dapat memahami nilai dan ekspektasi apa saja yang pantas atau yang dapat diterima untuk berinteraksi dengan rekan-rekannya dalam aliansi.

Dalam proses kedua, menantang batasan memperlihatkan negara yang mencari kemerdekaan/kebebasan dari aliansi. Menantang batasan termasuk dalam bidang soft balancing (penyeimbangan lembut). Proses terakhir dari Oposisi dalam Aliansi yaitu melanggar batasan, biasanya ditandai oleh meningkatnya ketidakpuasan dengan keanggotaan dalam aliansi dan meningkatnya keinginan untuk transisi menuju hard balancing (penyeimbangan keras). Dalam melanggar batasan, negara mencari kebebasan dan semakin terlibat dalam perilaku kebijakan luar negeri yang merusak integritas aliansi. Bentuk ketiga dari Oposisi dalam Aliansi ini biasanya menyaksikan ancaman penyeimbangan militer negara terhadap anggota aliansi atau aliansi itu sendiri.

Konsep Oposisi dalam Aliansi lebih lanjut menyatakan bahwa ketiga kategori perilaku Oposisi dalam Aliansi yang diidentifikasi di sini tidak saling terpisah dari yang lain dan ada kontinum dan konvergensi di antara mereka. Penting untuk menggarisbawahi bahwa 'menguji batasan' tidak selalu akan mengarah pada 'menantang batasan', dan 'menantang batasan' tidak secara otomatis menyebabkan 'melanggar batasan'. Suatu waktu, negara dapat kembali ke perilaku Oposisi dalam Aliansi berintensitas rendah, asalkan tidak ada kerusakan yang tidak dapat diperbaiki untuk dinamika dalam aliansi.

\section{Sikap Turki Dalam Menguji Batasan Norma NATO}

Bagian pertama dari tulisan ini akan menggunakan indikator Diplomasi Menjerat untuk melihat penggunaan aturan dan prosedur dari institusi (NATO) oleh Turki dalam mempengaruhi kebijakan luar negeri negara anggota NATO lainnya.

\section{Diplomasi Menjerat Turki Dalam NATO}

Entangling Diplomacy (Diplomasi Menjerat) merujuk pada penggunaan aturan dan prosedur dari institusi internasional dengan tujuan untuk memengaruhi kebijakan luar negeri negara anggota lainnya (Dursun-Ozkanca, 2019: 33). Sejak berlangsungnya perang di Suriah, anggota NATO tidak bisa mendapatkan konsensus bersama terkait masa depan Suriah. Dalam konflik di Suriah, negara anggota NATO bertindak masingmasing dan mengejar kepentingan mereka. Hal ini terlihat antara lain pada kebijakan 
Turki di Suriah yang mendapatkan pertentangan dari anggota lainnya. Bagi Turki, keamanan menjadi kekhawatiran utamanya, terkhusus dalam menangani organisasi teroris YPG/PYD. Sebaliknya, beberapa negara anggota NATO lainnya masih menanggap YPG/PYD sebagai sekutu mereka dalam perlawanan terhadap ISIS/Daesh, yang kemudian memperumit situasi.

Setelah serangan yang dilakukan oleh pasukan pemerintah Suriah terhadap pasukan Turki di Idlib, Suriah yang menewaskan 33 pasukan Turki, pemerintah Turki telah menyerukan pertemuan darurat NATO (BBC News, 2020). Di bawah pasal 4 Perjanjian NATO, ketika suatu anggota aliansi merasa integritas teritorial, kebebasan politik atau keamanannya terancam, maka negara tersebut dapat mengajukan sebuah konsultasi dengan semua anggota aliansi (NATO, 2020). Meskipun demikian proses ini tidak bisa diartikan bahwa NATO akan mendukung serangan militer Turki di Suriah.

Sesudah pertemuan itu berlangsung, Sekretaris Jenderal NATO, Jens Stoltenberg, mengungkapkan solidaritas dan dukungan penuhnya kepada Turki. Selanjutnya, perhatian pun ditujukan pada anggota NATO dan apakah akan ada bantuan signifikan kepada pasukan Turki di Suriah. Setelah pertemuan darurat dilaksanakan, Pasal 5 Perjanjian NATO, yang mencakup intervensi untuk melindungi negara-negara anggota NATO, telah diangkat kembali. Beberapa negara anggota menolak kasus yang diangkat Turki dengan alasan bahwa serangan terhadap pasukan Turki tidak terjadi di wilayah Turki, dan Pasal 5 hanya berlaku jika anggota aliansi diserang di wilayahnya (Guzel, 2020).

Dari sini, bisa dikatakan bahwa Turki berusaha untuk mendapatkan dukungan dari anggota NATO dengan menggunakan prosedur NATO yaitu dalam pasal 5. Pasal tersebut berisikan prinsip pertahanan kolektif yakni sebuah serangan terhadap satu anggota dianggap sebagai serangan terhadap seluruh anggota aliansi (NATO, 2019). Namun penolakan dari NATO dalam memberikan bantuan kepada Turki telah menjadi penanda adanya ketidaksepakatan dalam aliansi terkait ancaman. Sesuai dengan proses pertama dalam boundary testing (menguji batasan aliansi), Turki telah melakukan pengujian terhadap norma/nilai yang dipegang oleh NATO melalui entangling diplomacy dengan tujuan untuk mengubah sikap NATO, namun tidak didapatkan hasil yang memuaskan.

\section{Sikap Turki Dalam Menantang Batasan Norma NATO}

Bagian ini mengaplikasikan indikator Costly Signalling (Pensinyalan Merugikan) yang dipakai Turki dalam menantang batasan dalam NATO. Sejauh mana Turki mengambil sikap yang yang bertentangan dari NATO terkait masalah YPG? Pertanyaan ini akan dieksplorasi lebih lanjut dalam bagian selanjutnya. 


\section{Pensinyalan Merugikan Turki di Suriah}

Sejak kemunculan ISIS pada April 2013, kelompok teroris tersebut telah menetapkan wilayah yang ditentukan; namun, wilayah yang diklaimnya masih di bawah otoritas Irak dan Suriah. Dengan demikian, ISIS tidak memiliki pengakuan de jure atas wilayahnya. Meskipun demikian, populasi di dalam wilayah yang diklaim ISIS memandang ISIS adalah pemerintah resmi mereka, dan mereka diklasifikasikan sebagai 'warga negara' ISIS (Tobing \& Indradjaja, 2019: 107). Selain itu, terdapat kecenderungan dari kelompok teroris kontemporer untuk mengambil sebagian wilayah dan bahkan menantang kedaulatan suatu negara. Hal ini dilihat dari ISIS yang telah menunjukkan anomali, di mana mereka menundukkan wilayah dan bertindak seperti pemerintah negara alih-alih menciptakan ketakutan dan ketidakpastian seperti yang biasanya dilakukan (Ramadhan, 2019: 122-123).

Perlawanan terhadap ISIS menjadi salah satu prioritas NATO. Namun sikap Turki dalam perlawanan tersebut dapat digambarkan sebagai berlawanan arah. Sementara NATO berusaha untuk memusnahkan ISIS, di sisi lain Turki memfokuskan usahanya pada penggulingan Presiden Suriah, Bashar Al Assad, antara lain dengan membiarkan wilayah kedaulatannya digunakan oleh pasukan ISIS. Sebuah laporan Kementerian Dalam Negeri Jerman yang bocor pada Agustus 2016 mengklaim bahwa "sebagai hasil dari kebijakan domestik dan luar negeri Turki yang telah 'di-Islam-kan' selangkah demi selangkah sejak 2011, Turki telah berkembang menjadi platform aksi utama bagi kelompok-kelompok Islamis di wilayah Timur Tengah" (Moore, 2016).

Fokus lain yang tidak kalah pentingnya bagi Turki adalah suku Kurdi. Pasukan militer Turki memasuki Suriah pada Agustus 2016, namun operasinya di Suriah bukan menargetkan ISIS, melainkan pasukan Kurdi (YPG) dari Pasukan Pertahanan Suriah (SDF). SDF merupakan pasukan yang diandalkan NATO dalam melawan ISIS di darat (Toksabay \& McDowall, 2016). Bagi Turki, mencegah konsolidasi suku Kurdi di Suriah adalah sebuah prioritas, bukan melawan ISIS.

Dalam sebuah pidato pada awal bulan Oktober, 2016, Erdogan menyatakan, “Mulai sekarang kita tidak akan menunggu masalah datang mengetuk pintu kita, kita tidak akan menunggu sampai pisau mengenai tulang dan kulit kita, dan kita tidak akan menunggu organisasi teroris untuk datang dan menyerang kita" (Toksabay \& McDowall, 2016). Pidato tersebut datang setelah Turki melancarkan operasi militer 'Euphrates Shield' di Suriah. Berbeda dari NATO, ketika Erdogan mengacu pada organisasi teroris, yang ia maksud bukanlah ISIS, melainkan pasukan Kurdi. Dari sini kita bisa melihat bahwa Turki mengirimkan intensi niatnya untuk bertindak secara unilateral terlepas dari sikap anggota aliansi. 
Sikap Turki yang ambivalen dalam melawan ISIS juga terlihat dari keengganan Turki untuk memperketat perbatasannya dengan Suriah. Turki telah membiarkan perbatasannya terbuka sehingga pemberontak Suriah dapat lalu-lalng dengan bebas di wilayah antara Turki dan Suriah untuk mendapatkan bantuan logistik dalam menghadapi pasukan pemerintah Assad. Namun, kebijakan perbatasan-terbuka Turki juga membolehkan pasukan ISIS dari seluruh dunia untuk masuk Suriah atau keluar Suriah.

Negara-anggota NATO bersikap kritis terhadap longgarnya pengawasan Turki di wilayah perbatasannya dengan Suriah. Antara lain, mantan Menteri Pertahanan Amerika Serikat, Ashton Carter, pernah mengatakan bahwa satu kontribusi paling penting yang dapat dilakukan Turki dalam menghadapi ISIS adalah untuk mengontrol perbatasan mereka sendiri (Idiz, 2016).

Pada fase awal perang sipil Suriah, Turki terlihat telah berkoordinasi secara aktif dengan pemberontak Islamis yang berafiliasi dengan organisasi teroris Jabhat al-Nusra untuk menyediakan bantuan persenjataan untuk melawan rezim Assad (Abramowitz \& Eric, 2015: 14). Jabhat al-Nusra pada awalnya merupakan kelompok teroris, namun berubah menjadi kelompok insurgensi di Suriah dengan tujuan untuk menjatuhkan rezim Assad (Kamrullah, 2017: 85-86). Ini merupakan indikasi atas pensinyalan merugikan yang dilakukan Turki, karena dengan kebijakan perbatasan-terbukanya, Turki sekarang memiliki sleeper cells ISIS di dalam wilayah teritorialnya.

Turki tentu juga merasa khawatir perihal ancaman yang diajukan ISIS terhadap keamanan nasionalnya, namun, Turki terlihat lebih khawatir mengenai PKK dan akuisisi kekuasaan afiliasi PKK di wilayah utara Suriah. Erdogan mengatakan bahwa Turki "tidak akan pernah mengizinkan pendirian negara Kurdi di perbatasan selatan Turki di wilayah utara Suriah" (Almukhtar \& Wallace, 2015). Dengan memperpanjang proses pengambilan keputusan untuk memasuki perang melawan ISIS, Turki berkeinginan untuk meningkatkan biaya bagi Amerika Serikat dan sekutunya yang terlibat dalam perang melawan ISIS, dan sebagai akibatnya meningkatkan pengaruh Turki vis-à-vis Amerika Serikat untuk meyakinkan Amerika Serikat agar memilih Turki, bukan Kurdi.

Dalam menghadapi keterlibatan Rusia dan Iran di Suriah dan Irak, Amerika Serikat memutuskan untuk segera mengambil tindakan. Situasi ini menempatkan Amerika Serikat dalam posisi untuk memilih mitra yang sesuai (Kurdi Suriah), daripada mitra ideal (Turki), sebuah negara dengan militer terbesar kedua di NATO, dalam perang melawan ISIS. Oleh karena itu, perhitungan Turki dalam bermain waktu dan melakukan pensinyalan merugikan untuk meningkatkan pengaruhnya vis-à-vis Amerika Serikat tidak membuahkan hasil. Sebaliknya, ISIS mulai melakukan lebih banyak serangan teroris di Turki (Dalay, 2017), (Erdogan, 2017). 
ISIS telah menargetkan rakyat Turki dan fasilitas mereka melalui aksi pemboman dan mengganggu keamanan di daerah perbatasan. Kelompok bersenjata itu merupakan ancaman nyata bagi stabilitas serta rakyat Turki dan dianggap sama berbahayanya dengan PKK bagi persatuan negara (Luerdi, 2019: 60). Ini menggarisbawahi besarnya biaya manusia dari kebijakan ambivalen yang ditampilkan Turki dalam pertarungannya terhadap ISIS.

\section{Sikap Turki Dalam Melanggar Batasan Norma NATO}

Bagian ini akan menganalisis sikap Turki terhadap NATO dalam kategori terakhir oposisi intra-aliansi yaitu boundary breaking, dan akan mengaplikasikan Compellent Threats (Ancaman yang Memaksa), dan Blackmailing (Pemerasan) sebagai alat yang digunakan Turki dalam NATO.

\section{Ancaman yang Memaksa}

Compellent Threats (Ancaman yang Memaksa) berkisar pada konsep koersi militer untuk mengubah status quo. Biasanya, tujuannya adalah untuk menakuti lawan agar melepaskan kepemilikan yang berharga atau mengubah perilakunya. Ancaman ini biasanya digunakan dalam wilayah yang disengketakan, pembayaran reparasi, atau pembalikan kebijakan yang tidak menguntungkan (Sechser \& Fuhrmann, 2013: 173195). Ancaman ini dikategorikan terbaik sebagai alat kenegaraan yang digunakan dalam melanggar batasan. Namun, jika ancaman tidak cukup kredibel, alat ini bisa juga dikategorikan dalam menantang batasan. Dalam tulisan ini, Ancaman yang Memaksa akan diaplikasikan dalam melanggar batasan akibat sikap koersif Turki terhadap Amerika Serikat.

Turki memandang YPG sebagai organisasi teroris dan sebagai perpanjangan dari kelompok Kurdi PKK yang telah melaksanakan pemberontakan selama tiga dekade terhadap Turki untuk mendapatkan otonomi. Namun Amerika Serikat memandang YPG sebagai mitranya yang paling efektif di lapangan dalam melakukan perlawanan terhadap ISIS di Suriah. Perbedaan persepsi ini menjadi cerita utama dari hubungan antara kedua negara anggota NATO di Suriah.

Pada 1 Mei 2017, Turki melakukan serangan udara terhadap posisi Kurdi di Suriah, yang mengindikasikan kepentingan yang saling bertabrakan antara Amerika Serikat dan Turki. Serangan tersebut terjadi dekat dengan tempat di mana para pasukan khusus Amerika Serikat ditempatkan. Turki mengeluarkan sebuah peringatan kepada Amerika Serikat terkait serangan tersebut setengah jam sebelum dilaksanakan (McLeary, 2017), memperlihatkan bahwa merupakan sebuah strategi yang berisiko untuk menyebarkan pasukan Amerika Serikat di samping pasukan Kurdi. 
“Apabila pasukan Kurdi dan Amerika Serikat tetap bekerjasama, kita tidak akan mempertimbangkan fakta bahwa terdapat kendaraan lapis baja Amerika Serikat... Tibatiba, secara tidak sengaja, beberapa roket dapat mengenai mereka," demikian dikatakan Ilnur Cevik, seorang penasihat politik Erdogan dalam sebuah interview radio (McLeary, 2017). Pernyataan dari datang sesaat setelah Amerika Serikat mengirimkan kendaraan lapis baja di perbatasan Turki dan Suriah, menciptakan buffer zone (daerah penyangga) antara pasukan Turki di Utara dan pasukan Kurdi di Selatan (Chulov \& Hawramy, 2017).

Ancaman terselubung dari Turki ini memperkuat argumen bahwa Turki telah berubah sikap terhadap aliansi NATO, menandakan bahwa Turki bersedia untuk terlibat dalam boundary breaking dengan NATO melalui penggunaan ancaman yang memaksa. Pada 20 Januari 2018, Turki melancarkan operasi militer yang dikenal dengan nama Olive Branch, di Suriah yang ditujukan untuk memukul mundur pasukan YPG dari kota Afrin, Suriah (BBC News, 2018). Selanjutnya kota Manbij menjadi titik temu antara kedua negara anggota NATO tersebut (Munoz, 2018). Pasukan khusus Amerika Serikat yang berbasiskan di Manbij telah menghindari pasukan Turki yang melakukan serangan terhadap pasukan Kurdi di Afrin. Namun Presiden Erdogan memutuskan untuk memperluas operasi Olive Branch ke arah timur Suriah yang dikuasai Amerika Serikat. Ini merupakan momen yang bahaya bagi Turki dan Amerika Serikat.

Ketegangan meningkat setelah Turki mengumumkan akan menarget kota Manbij apabila YPG tidak mengundurkan diri dari kota tersebut. "Jika YPG tidak mundur dari Manbij, maka kami akan pergi ke Manbij, kami akan pergi ke timur Eufrat," kata Wakil Perdana Menteri Turki Bekir Bozdag. Bozdag menambahkan, bahwa pasukan Amerika Serikat dapat menjadi sasaran oleh pasukan Turki yang pindah ke Manbij jika mereka terlihat mengenakan seragam YPG. "Jika mereka mendatangi kita dengan seragam seperti itu, kita akan melihat mereka sebagai teroris," (Munoz, 2018). Pernyataan tersebut datang mengingat pada tahun 2016 beberapa penasihat operasi khusus Amerika yang berbasis di Manbij difoto mengenakan lencana YPG (Calamur, 2016). Presiden Trump kemudian menyetujui kesepakatan tentang Manbij yang memaksa YPG keluar dari kota strategis tersebut dan timur dari Sungai Eufrat, memenuhi tuntutan Turki tanpa mendapatkan apa pun yang nyata sebagai imbalannya (Cook, 2018).

Anggota aliansi NATO mengkritik keras operasi militer Turki di Suriah. Salah satunya adalah Prancis di mana pada 13 Maret 2018, Menteri Luar Negeri Jean Yves Le Drian membuat pernyataan di parlemen bahwa operasi Turki terhadap YPG di wilayah Afrin tidak bisa dibenarkan (Reuters, 2018). Ini merupakan pernyataan terkuat yang dilontarkan oleh Perancis terkait intervensi sekutu NATO di Suriah. Prancis, sama halnya dengan Amerika Serikat, menyediakan persenjataan dan pelatihan kepada milisi YPG 
dalam perlawanannya terhadap ISIS di Suriah, serta juga memiliki beberapa pasukan khusus yang berbasis di wilayah tersebut.

Saat ditanyakan terkait operasi militer Turki di Suriah, dalam sebuah konferensi pers di Madrid, Sekretaris Jenderal NATO, Jens Stoltenberg, menyatakan, "Turki merupakan sekutu NATO yang telah paling banyak menderita dari serangan teroris selama bertahun-tahun dan Turki, sama seperti negara lain, memiliki hak atas pertahanan diri, namun penting agar dilakukan dengan cara sebanding dan terukur" (Stoltenberg \& Dolores, 2018). NATO sendiri berperan dalam koalisi global untuk menghadapi ISIS, dengan menyediakan bantuan pesawat pengintai AWACS dan pelatihan di Irak, namun NATO tidak hadir di Suriah Utara. Di sini terlihat jelas perbedaan tujuan di antara sesama anggota NATO; tujuan utama NATO di Suriah adalah untuk membasmi ISIS, namun Turki menjalankan kebijakan yang berbeda dari NATO, dan memilih untuk menghadapi YPG secara unilateral.

\section{Pemerasan Turki Atas Rencana Pertahanan Baltik NATO}

Pada awal Desember 2019, Turki melakukan pemblokiran terhadap sebuah rencana pertahanan untuk Polandia dan negara-negara Baltik hingga NATO mengakui bahwa YPG merupakan sebuah ancaman teroris yang perlu diatasi (Wintour, 2019). Rencana pertahanan bagi ini dikemukakan setelah Rusia mencaplok Krimea dari Ukraina pada tahun 2014 (Emmott \& Irish, 2020). Mereka menginginkan pertahanan dari NATO disebabkan oleh letak geografis mereka dengan Rusia, yang mereka takuti akan melakukan hal yang sama terhadap mereka seperti halnya Krimea.

Turki mengklaim bahwa ia memiliki hak veto penuh atas proposal apa pun di dalam NATO. "NATO sendiri menjadi institusi di mana Turki memiliki hak veto penuh, secara politik dan militer," demikian pernyataan dari pemerintahan Turki. Selanjutnya Presiden Erdogan menyatakan, "Apabila NATO tidak mengakui organisasi teroris seperti yang kami pandang sebagai organisasi teroris, kami akan menentang langkah apa pun yang akan diambil di sana" (Marcus, 2019). Meskipun Turki menyetujui rencana tersebut-dikenal sebagai Eagle Defender-namun Turki telah menolak para pimpinan militer NATO untuk menjalankan rencana tersebut (Emmott \& Irish, 2020).

Rencana pertahanan tersebut tidak memiliki implikasi langsung terhadap strategi Turki di Suriah, namun hal itu menimbulkan masalah tentang keamanan bagi seluruh anggota NATO. Di bawah piagam NATO, sebuah serangan terhadap satu anggota adalah serangan terhadap semua, dan NATO memiliki strategi militer untuk pertahanan kolektif. Dengan demikian Turki telah menjadikan rencana pertahanan NATO sebagai daya tawar baginya, di mana Turki akan menyetujui rencana pertahanan tersebut dengan konsesi NATO mengakui YPG sebagai kelompok teroris. 
Sikap Turki di sini telah mengancam kepentingan dari anggota NATO terkhusus Polandia dan negara-negara Baltik dalam segi pertahanan mereka. Perselisihan ini menjadi tanda bahwa perbedaan masih tetap hadir antara Turki, Prancis dan Amerika Serikat atas operasi militer Operation Peace Spring yang dilancangkan oleh Turki pada awal Oktober 2019 di Suriah Utara. Turki melakukan ofensif ke Suriah Utara setelah Amerika Serikat menarik kembali seribu pasukannya dari wilayah tersebut pada awal Oktober 2019. Turki mengatakan bahwa serangan yang dilakukan di Suriah Utara dirancang untuk membentuk sebuah safe zone yang ditujukan untuk melemahkan YPG (Al Jazeera, 2019).

Serangan ini dikecam oleh anggota NATO, antara lain Presiden Prancis, Macron. Macron memperingatkan tindakan tersebut akan melemahkan peran YPG dalam melawan ISIS dan memperumit upaya-upaya untuk mengamankan sebuah perjanjian perdamaian di seluruh wilayah Suriah. Inggris dan Jerman juga mengkritik tindakan Turki, meskipun melihat bahwa kritikan terhadap Turki akan menjadi bencana apabila Turki memutuskan untuk mengeluarkan diri dari NATO, dan mencari aliansi lain dengan Rusia (Wintour, 2019).

Berdasarkan uraian di atas, dapat disimpulkan bahwa Turki telah menggunakan tiga variabel Oposisi dalam Aliansi. Pertama Turki telah menguji nilai dan norma aliansi dengan memicu aturan/prosedur dalam NATO tanpa hasil yang memuaskan. Kedua Turki mencoba menggunakan jalur soft balancing dengan tujuan mendapatkan dukungan dari Amerika Serikat dalam melawan YPG, namun Amerika Serikat memilih YPG sebagai mitranya dalam melawan ISIS. Ketiga, Turki telah bersedia untuk bertransisi menuju hard balancing dalam relasinya dengan sesama aliansi. Sikap Amerika Serikat dan NATO yang mengabaikan Turki dalam mendukung prioritas keamanannya telah membuka kotak Pandora bagi relasi Turki dengan anggota NATO lainnya. Pada akhirnya Turki take matters into its own hands (menangani masalah dengan caranya sendiri).

\section{Simpulan}

Tulisan ini berargumen bahwa perbedaan posisi antara Turki dengan anggota NATO lainnya terkait peran pasukan Kurdi Suriah dalam menghadapi ISIS membentuk motivasi bagi Turki untuk melepaskan diri dari NATO. Tulisan ini memperlihatkan bukti sikap menantang batasan Turki terhadap NATO mengingat keengganannya dalam bergabung dalam berperang menghadap ISIS, longgarnya pengendalian perbatasannya dengan Suriah, dan sikap melanggar batasan yang semakin meningkat melalui berbagai retorika ancaman militer kepada sekutu NATO, salah satunya Amerika Serikat, dan tindakan pemerasan terhadap Polandia dan negara-negara Baltik yang merupakan sekutunya dalam NATO. 
Seperti yang ditunjukkan oleh hubungan Turki-Amerika Serikat di Suriah, kebijakan Turki semakin memperlihatkan kecenderungan melanggar batasan dengan Amerika Serikat dan NATO melalui penggunaan alat-alat penyeimbangan yang lebih tradisional seperti ancaman yang memaksa, dan pemerasan. Pengabaian lebih lanjut oleh NATO terhadap kepentingan keamanan Turki menjalankan risiko meningkatnya ketegangan hubungan Turki-NATO serta penyelarasan kebijakan luar negeri dan militer Turki dengan Rusia. Oleh sebab itu, sangat penting bagi Turki dan anggota NATO lainnya untuk bekerja sama dan memperkuat kemitraan transatlantik demi tujuan strategis bersama.

\section{Daftar Pustaka}

Abramowitz, M. dan Eric, E. (2015). Turkey: An Increasingly Undependable Ally. [online] Bipartisan Policy Center. Dalam: https://bipartisanpolicy.org/report/turkey-anincreasingly-undependable-ally/ [Diakses 29 Mei 2020].

Al Jazeera. (2019). Turkey begins ground offensive in northeastern Syria. [online]. Dalam: https://www.aljazeera.com/news/2019/10/turkey-begins-ground-offensivenortheastern-syria-191009212025006.html [Diakses 2 Juni 2020].

Almukhtar, S. dan Wallace, T. (2015). Why Turkey Is Fighting the Kurds Who Are Fighting ISIS. The New York Times, [online]. Dalam: https://www.nytimes.com/interactive/2015/08/12/world/middleeast/turkeykurds-isis.html [Diakses 2 Juni 2020].

Altunisik, M. (2013). The Middle East in Turkey-USA Relations: Managing the Alliance. Journal of Balkan and Near Eastern Studies, [online] 15(2), 157-173. Dalam: https://doi.org/10.1080/19448953.2013.775036 [Diakses 3 Juni 2020].

Anderson, E. dan Anderson, L. (2013). An Atlas of Middle Eastern Affairs. Ed.2. London: Routledge.

Ara News. (2016). Netherlands demanding Turkey to work with the Kurds in Syria. [online]. Dalam: http://aranews.net/files/2016/08/netherlands-demandingturkey-work-kurds-syria/ [Diakses 4 Juni 2020].

BBC News. (2018). Syria war: Turkey suffers deadliest day in Afrin offensive. [online]. Dalam: https://www.bbc.com/news/world-middle-east-42934041 [Diakses 4 Juni 2020].

BBC News. (2019). Turkey v Syria's Kurds: The short, medium and long story. [online]. 
Dalam: https://www.bbc.com/news/world-middle-east-49963649 [Diakses 4 Juni 2020].

BBC News. (2020). Syria war: Alarm after 33 Turkish soldiers killed in attack in Idlib. [online]. Dalam: https://www.bbc.com/news/world-middle-east-51667717 [Diakses 4 Juni 2020].

Calamur, K. (2016). Reversing Course on U.S. Soldiers Wearing Kurdish Rebel Insignia. The Atlantic, [online]. Dalam: https://www.theatlantic.com/international/archive/2016/05/turkey-usypg/484631/ [Diakses 7 Juni 2020].

Chulov, M. dan Hawramy, F. (2017). Ever-closer ties between US and Kurds stoke Turkish border tensions. The Guardian, [online]. Dalam: https://www.theguardian.com/world/2017/may/01/tensions-rise-along-theturkey-syria-border-pkk-ypg-erdogan [Diakses 7 Juni 2020].

Cook, S. (2018). Neither Friend nor Foe: The Future of U.S.-Turkey Relations. [online] Council on Foreign Relations. Dalam: https://www.cfr.org/report/future-u.s.turkey [Diakses 8 Juni 2020].

Dalay, G. (2017). Turkey's Unpalatable Choices in Syria. [online] German Marshall Fund of the United States. Dalam: https://www.gmfus.org/publications/turkeysunpalatable-choices-syria [Diakses 9 Juni 2020].

Dursun-Ozkanca, O. (2019). Turkey-West Relations: The Politics of Intra-alliance Opposition. Cambridge University Press.

Emmott, R. dan Irish, J. (2020). Turkey still blocking defence plan for Poland, Baltics, NATO envoys say. Reuters, [online]. Dalam: https://www.reuters.com/article/usnato-france-turkey-plans/turkey-still-blocking-defence-plan-for-poland-balticsnato-envoys-say-idUSKBN2301TN [Diakses 10 Juni 2020].

Erdogan, E. (2017). Presidential Referendum: A Pivotal Moment in Turkey's Prolonged Election Cycle. [online] German Marshall Fund of the United States. Dalam: https://www.gmfus.org/publications/presidential-referendum-pivotal-momentturkeys-prolonged-election-cycle [Diakses 10 Juni 2020].

Erickson, E. (2004). Turkey as regional hegemon-2014: strategic implications for the United States. Turkish Studies, [online] 5(3), 25-45. Dalam: https://doi.org/10.1080/1468384042000270317 [Diakses 10 Juni 2020]. 
Fathurachmi, E. (2014). Intractable Conflict in Southern Thailand. Insignia: Journal Of International Relations, [online] 1(1), 1-10. Dalam: https://doi.org/10.20884/1.ins.2014.1.01.414 [Diakses 10 Juni 2020].

Gurcay, E. (t.t.). [online] Middle East Policy Council. Dalam: https://mepc.org/commentary/us-ypg-relationship-us-foreign-policy-futurekurds-syria-and-turkey [Diakses 11 Juni 2020].

Guvenc, S. dan Ozel, S. (2012). NATO and Turkey in the post-Cold War world: between abandonment and entrapment. Southeast European and Black Sea Studies, [online] 12(4), 533-553. Dalam: https://doi.org/10.1080/14683857.2012.741845 [Diakses 11 Juni 2020].

Guzel, E. (2020). Idlib and a watershed moment for NATO-Turkey relations. Daily Sabah, [online]. Dalam: https://www.dailysabah.com/opinion/op-ed/idlib-and-awatershed-moment-for-nato-turkey-relations [Diakses 12 Juni 2020].

Hurriyet Daily News. (2016). France criticizes Turkish military operation in Syria. [online]. Dalam: https://www.hurriyetdailynews.com/france-criticizes-turkish-militaryoperation-in-syria-103393 [Diakses 12 Juni 2020].

Hurriyet Daily News. (2017). Turkey can start new operation if necessary as Euphrates Shield ends: PM. [online]. Dalam: https://www.hurriyetdailynews.com/turkeycan-start-new-operation-if-necessary-as-euphrates-shield-ends-pm--111401 [Diakses 13 Juni 2020].

Idiz, S. (2016). Turkish-US ties face fresh turbulence over Iraq, Syria. Al-monitor, [online]. Dalam: $\quad$ https://www.al-monitor.com/pulse/originals/2016/01/turkey-usarelations-iraq-syrian-kurds-potential-flashpoints.html [Diakses 13 Juni 2020].

Kamrullah, M. (2017). Peran Jabhat Al-Nusra dalam Memberikan Tantangan terhadap Kebijakan Amerika Serikat Mendukung Kelompok Oposisi pada Konflik Bersenjata di Suriah. Global: Jurnal Politik Internasional, [online] 19(2), 77-97. Dalam: https://doi.org/10.7454/global.v19i2.287 [Diakses 14 Juni 2020].

Kardas, S. (2013). Turkey: A Regional Power Facing a Changing International System. Turkish Studies, [online] 14(4), 637-660. Dalam: https://doi.org/10.1080/14683849.2013.861111 [Diakses 14 Juni 2020].

Kinacioglu, M. dan Gurzel, A. (2013). Turkey's Contribution to NATO's Role in Post-Cold War Security Governance: The Use of Force and Security Identity Formation. 
Global Governance, [online] 19(4), 589-610. Dalam: https://doi.org/10.1163/19426720-01904007 [Diakses 14 Juni 2020].

Luerdi, L. (2019). Turkish Domestic Actors' Role in Foreign Policy Making: Case of Turkey - KRG's Strategic Bilateral Partnership. Global: Jurnal Politik Internasional, [online] 21(1), 48-69. Dalam: https://doi.org/10.7454/global.v21i1.347 [Diakses 15 Juni 2020].

Marcus, J. (2019). NATO summit: Divisions exposed ahead of meeting. BBC News, [online]. Dalam: https://www.bbc.com/news/world-europe-50635593 [Diakses 15 Juni 2020].

Martin, L. (2013). Turkey and the USA in a Bipolarizing Middle East. Journal of Balkan and Near Eastern Studies, [online] 15(2), 175-188. Dalam: https://doi.org/10.1080/19448953.2013.775037 [Diakses 16 Juni 2020].

McLeary, P. (2017). Turkey Threatens US Forces in Syria, as Putin Presses for Safe Zones. [online] Foreign Policy. Dalam: https://foreignpolicy.com/2017/05/03/turkeythreatens-u-s-forces-in-syria-as-putin-presses-for-safe-zones/ [Diakses 16 Juni 2020].

Moore, J. (2016). Leaked German Report Calls Turkey Platform For Hamas, Muslim Brotherhood, Syrian Rebel Groups. Newsweek, [online]. Dalam: https://www.newsweek.com/leaked-german-report-calls-turkey-platformhamas-muslim-brotherhood-syrian-490963 [Diakses 17 Juni 2020].

Munoz, C. (2018). U.S., Turkish forces on course for clash in Syrian town. The Washington Times, [online]. Dalam: https://www.washingtontimes.com/news/2018/feb/5/turkey-us-forces-courseclash-manbij-syria/ [Diakses 17 Juni 2020].

NATO, (2019). Collective defence - Article 5. [online] Dalam: https://www.nato.int/cps/en/natohq/topics_110496.htm\# [Diakses 17 Juni 2020].

NATO, (2020). The consultation process and Article 4. [online] Dalam: https://www.nato.int/cps/en/natohq/topics_49187.htm\#: :text=The\%20article\% 20states\%3A,of\%20the\%20North\%20Atlantic\%20Treaty. [Diakses 17 Juni 2020]. 
Oguzlu, T. (2008). Middle Easternization of Turkey's Foreign Policy: Does Turkey Dissociate from the West? Turkish Studies, [online] 9(1), 3-20. Dalam: https://doi.org/10.1080/14683840701813960 [Diakses 18 Juni 2020].

Oguzlu, T. (2012). Turkey's Eroding Commitment to NATO: From Identity to Interests. The Washington Quarterly, [online] 35(3), 153-164. Dalam: https://doi.org/10.1080/0163660X.2012.706578 [Diakses 18 Juni 2020].

Oguzlu, T. (2013a). Making Sense of Turkey's Rising Power Status: What Does Turkey's Approach Within NATO Tell Us? Turkish Studies, [online] 14(4), 774-796. Dalam: https://doi.org/10.1080/14683849.2013.863420 [Diakses 18 Juni 2020].

Oguzlu, T. (2013b). Testing the Strength of the Turkish-American Strategic Relationship through NATO: Convergence or Divergence within the Alliance? Journal of Balkan and Near Eastern Studies, [online] 15(2), 207-222. Dalam: https://doi.org/10.1080/19448953.2013.775759 [Diakses 18 Juni 2020].

Onis, Z. dan Kutlay, M. (2016). The dynamics of emerging middle-power influence in regional and global governance: the paradoxical case of Turkey. Australian Journal of International Affairs, [online] 71(2), 164-183. Dalam: https://doi.org/10.1080/10357718.2016.1183586 [Diakses 19 Juni 2020].

Parlal Dal, E. (2016). Conceptualising and testing the 'emerging regional power' of Turkey in the shifting international order. Third World Quarterly, [online] 37(8), 1425-1453. Dalam: https://doi.org/10.1080/01436597.2016.1142367 [Diakses 19 Juni 2020].

Parlar Dal, E. (2017). Impact of the transnationalization of the Syrian civil war on Turkey: conflict spillover cases of ISIS and PYD-YPG/PKK. Cambridge Review of International Affairs, [online] 29(4), 1396-1420. Dalam: https://doi.org/10.1080/09557571.2016.1256948 [Diakses 19 Juni 2020].

Ramadhan, G. (2019). The Development of Concept of Territory in International Relations. Global: Jurnal Politik Internasional, [online] 20(2), 120-135. Dalam: https://doi.org/10.7454/global.v20i2.348 [Diakses 20 Juni 2020].

Reuters. (2018). Under pressure, France toughens talk on Turkish Syria operation. [online]. Dalam: https://www.reuters.com/article/us-mideast-crisis-syriafrance/under-pressure-france-toughens-talk-on-turkish-syria-operationidUSKCN1GP2EG [Diakses 20 Juni 2020]. 
Sayari, S. (2013). New Directions in Turkey-USA Relations. Journal of Balkan and Near Eastern Studies, [online] 15(2), 129-142. Dalam: https://doi.org/10.1080/19448953.2013.775022 [Diakses 21 Juni 2020].

Sechser, T. dan Fuhrmann, M. (2013). Crisis Bargaining and Nuclear Blackmail. International Organization, [online] 67(1), 173-195. Dalam: https://doi.org/10.1017/S0020818312000392 [Diakses 21 Juni 2020].

Stoltenberg, J. dan Dolores, M. (2018). Joint press conference. [Online] NATO. Dalam: https://www.nato.int/cps/ic/natohq/opinions_151089.htm?selectedLocale=en [Diakses 22 Juni 2020].

Sudira, I. (2017). Resolusi Konflik dalam Perubahan Dunia. Global: Jurnal Politik Internasional, [online] 19(2), 156-171. Dalam: https://doi.org/10.7454/global.v19i2.301 [Diakses 22 Juni 2020].

Tobing, F. dan Indradjaja, E. (2019). Islamic State in Iraq and Syria (ISIS) and Its Impact in Indonesia. Global: Jurnal Politik Internasional, [online] 21(1), 101-125. Dalam: https://doi.org/10.7454/global.v21i1.365 [Diakses 23 Juni 2020].

Toksabay, E. dan McDowall, A. (2016). Turkey bombs Syrian Kurdish militia allied to U.S.backed force. Reuters, [online]. Dalam: https://www.reuters.com/article/usmideast-crisis-syria-kurds/turkey-bombs-syrian-kurdish-militia-allied-to-u-sbacked-force-idUSKCN12KOER [Diakses 24 Juni 2020].

TRT World. (2020). Why do a majority of Turks have an unfavourable view of NATO? [online]. Dalam: https://www.trtworld.com/turkey/why-do-a-majority-of-turkshave-an-unfavourable-view-of-nato-33733 [Diakses 25 Juni 2020].

Uras, U. (2019). Turkey's Operation Peace Spring in northern Syria: One month on. Al Jazeera, [online]. Dalam: https://www.aljazeera.com/news/2019/11/8/turkeysoperation-peace-spring-in-northern-syria-one-month-on [Diakses 26 Juni 2020].

Walt, S. (1987). The Origins of Alliances. Cornell University Press.

Wintour, P. (2019). Turkey denies blackmailing NATO over Baltics defence plan. The Guardian, [online]. Dalam: https://www.theguardian.com/world/2019/dec/02/turkey-denies-blackmailingnato-over-baltics-defence-plan [Diakses 28 Juni 2020].

Wiratma, H. dan Suharman, Y. (2016). Terorisme dan Keamanan Kolektif ASEAN. Insignia: Journal of International Relations, [online] 3(1), 11-19. Dalam: https://doi.org/10.20884/1.ins.2016.3.01.464 [Diakses 29 Juni 2020]. 
Zanotti, J. dan Thomas, C. (2017). Turkey: Background and US Relations in Brief. [online] Congressional Research Service Report. Dalam: https://fas.org/sgp/crs/mideast/R44000.pdf [Diakses 29 Juni 2020]. 